\title{
MEASURING OF THE NECTAR YIELD OF RED CLOVER HEADS
}

\author{
Juhani Paatela and Hannes Heinrichs \\ Department of Plant Husbandry, University of Helsinki
}

Received February 2, 1960

Red clover is almost entirely self sterile so that cross pollination is necessary for the development of seeds. The pollinators of red clover gather from the flowers apart from pollen in particular nectar. The obtaining of nectar can be difficult because of the length of the corolla tube or the small quantity of nectar in the flowers. Much more attention has been paid to the length of the corolla tube and its variations in different varieties, climatic conditions etc. than has been paid to the amount of nectar and its variations in corresponding cases $(2,4,6-12)$. This may arise from the lack of a suitable method of measuring the nectar yield.

The water extraction method of measuring the nectar yield gives only the amount of sugar contained in the nectar. The micro-pipette method (14) is preferable for many purposes. The centrifugal method is, however, more rapid than this and gives more useful results. The main principle is as follows: the red clover head is set in a glass tube and centrifuged, whereby the nectar under the influence of the centrifugal force is liberated from the flowers and accumulates in a column at the bottom of the narrow lower part of the tube, where its volume or weight can be easily measured $(3,4,12,13)$.

At the University Farm at.Viik an attempt was made in 1954 to develop the centrifuge method into a simple and quick routine-method. This was necessary to make an investigation of a great number of samples possible, and particularly, owing to the great variation in the amount of nectar in red clover heads, within each sample which thus comprised some $20-40$ heads. Besides the conditions prevalent on the field, and the grown varieties, the size and stage of development of the inflorescence can affect the variation of nectar content. In what follows attention is paid to some of the most important factors affecting the nectar yield and the centrifuge method itself.

\section{The taking and handling of the sample}

Probably the most important factor contributing to the fluctuation in the amount of nectar and its sugar content is the loose rain and dew between the flowers. Therefore the sample should be taken only at those times of the day when there is no more 
loose water in the heads. Therefore the heads harvested for a sample were shaken a few times against the back of the hand. If no drops of water appeared on the skin, the head was sufticiently dry.

The heads harvested for a sample had also to be of the same size and at the same known stage of development, as well as grown in the same microclimatic conditions, in other words, at the same height and in equally dense stands. The size of the heads and the blossom stage were estimated ocularly. The checking calculations indicated that the size of the head could be estimated on an average with an accuracy of about ten florets;. An effort was made to take the samples of heads middle-sized inflorescences consisting of about a hundred florets. To illustrate the significance of the size of inflorescence (number of florets) for the nectar yield, 48 large and small-sized heads at the same blossom stage were gathered. The average nectar yield of the 48 small heads was $18.2 \pm 1.80 \mu \mathrm{l}$ and that of large $33.4 \pm 2.24 \mu \mathrm{l}$. The difference between the average nectar yields of the large and small heads was highly significant $\left(\mathrm{t}=5.30^{* * *}\right)$. The average number of florets on the small heads was 83 and the average length of the corolla tubes $9.35 \mathrm{~mm}$, and correspondingly 112 and 9.73 for large heads. Calculated per hundred florets there was more nectar in the large $(29.8: \pm 4.42 \mu \mathrm{l})$ than in the small heads $(20.9 \pm 4.79 \mu \mathrm{l})$. The average nectar yields differed from each other highly significantly $\left(\mathrm{t}=9.47^{* * *}\right)$. The sugar content of the nectar of the large inflorescences was also higher $(34.9 \%)$ than that of the small heads; $(30.4 \%)$. This result indicates that the secretion of nectar and sugar is more rapid in the large heads than in the small sized ones grown in the same stand. Thus for obtaining representative results with a moderate number of heads the sample should be composed of inflorescences of as near as possible the same (medium) size.

Swanson and shuel (13) have investigated the effect of the blossom stage of the head on the quantity of the nectar yield. During the first day after full blossom no change in the amount of sugar was noticeable, but from the second day and during the third tie sugar yield per head decreased by two thirds. At the University Farm the sample; were taken when three uppermost verticils were just opening, in other words, the head was approaching the full bloom stage, which was easy to verify, even though the finding of a large number of heads might produce difficulties. An attempt was nade to take the samples from normally dense uncovered stands of about the same height. Perhaps more even results can be obtained from covered plots, because th? bumble-bees and bees are prevented from sucking nectar from the florets. However, in these too the hereditary differences in nectar yield cause a noticeably larg variation.

The harvested heads were gathered in plastic bags and taken quickly to the laboratory in order to prevent noteworthy changes in the content or the quality of the nectar yield. Swanson and Shuel investigated these changes and 132 clover heads were split lengthwise and one lot of half-heads was centrifuged one hour after harvesting, the other lot two hours after harvesting. The correlation coefficient for the nectar yield between the respective lots of half heads, based on a sample of 32 paired halves, was 0.73 . This value is the same as that obtained for the simultaneous centrifugation of paired halves ( 0.76 for a sample of 132 paired halves). The results for sugar concentration were similar. At the University Farm the harvesting, 
handling and examining of 48 samples lasted on an average about two hours, whereby during this period hardly any statistically notable changes occurred in the amount and quality of the nectar. In the handling of the samples the bract of the head was first removed. In accordance with the method employed $4-6 \mathrm{mms}$ were cut off from the tip of the florets to facilitate the excretion of the nectar. This procedure, however, proved to be laborious and lengthy. Even with careful cutting of the florets nectar stuck to the scissors. Moreover the floret snippets remained at the head, from which they were difficult to remove without damaging them. The necessity of this procedure was tested by centrifuging 40 cut and 40 uncut inflorescences. From the former an average of $35.0 \mu \mathrm{l}$ of nectar was obtained and from the latter $33.9 \mu \mathrm{l}$. The average sugar content of the nectar was correspondingly $33.4 \pm 0.98 \%$ and $35.0 \pm 0.93 \%$. The cutting of the heads was thereby shown to be unnecessary, at least when sufficiently large glass tubes were used.

\section{The glass tubes and the setting of heads in them}

The method employed by Swanson \& Shuel (13) is in its main features the following: the harvested inflorescences are set inside a frame made from two metal wires about $2.5 \mathrm{cms}$ high and $1.5 \mathrm{cms}$ wide fixed in the cork. From the opposite side a thin needle is inserted through the cork and into the floral axis. The cork is then inserted into the end of the prepared glass tube with the head pointing downwards. In the centrifugation the nectar exudes from the florets and collects in a column at the bottom of the narrow lower part of the tube, in which the volume is easily measured. The method proved in certain respects slow and laborious. Firstly it was difficult to insert the needle into the floral axis without breaking it, nor was the needle able to hold the inflorescence in position during centrifugation, since it easily became pressed against the frame beneath. Several florets were thus broken nor was the nectar able to flow freely from them. In addition part of the florets came loose twisting in the frame. The broad upper part of the glass tube, on which the heads were placed upside down, was not sufficiently large at least for large and uncut inflorescences resulting that part of the florets easily became attached to the glass wall of the tube thus preventing the nectar from flowing freely from all the florets. Another hindrance to the flowing of the nectar into the narrow lower part of the glass tube, into the capillary tube, lay in the fact that the upper part narrowed too sharply, so that part of the nectar remained on the wall of the upper part. The method employed by Stapel \& Götzsche (12), which forms a basis for the method employed by Gubin (4) and Evert (3), differs from the above particularly in the way of fastening the inflorescence; here part of the stem of the head is threaded through a hole made in the cork. The cork is placed in the glass tube inflorescence first and a second cork is inserted into the hole, whereby the stem of the inflorescence remains between both the corks. In inserting the upper cork the lower cork easily becomes so tightly wedged in the tube that its extraction is difficult, in addition to which the stems easily break. 
At Viik it was decided to fasten the heads as follows: the stem of the inflorescence is threaded through a hole in the rubber stopper and bent over the top of the stopper. Then a frosted glass wedge about $4 \mathrm{cms}$ long and a shade thicker than the hole in the stopper is carefully inserted into the hole (Fig. 1). Because of the soft and flexible wall of the rubber stopper, the stems are not easily crushed, and the frosted surface of the wedge prevents the stem or the wedge itself from slipping out of position. The rubber stopper is inserted head first in the glass tube (Fig. 2).

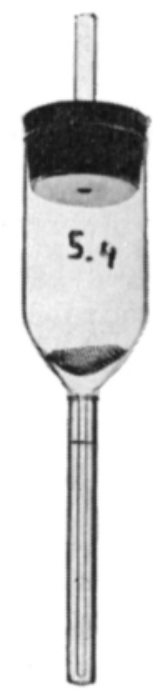

Figure 1. Glass tube with its capillary part, rubber stopper with hole, frosted glass wedge and brass gauze.

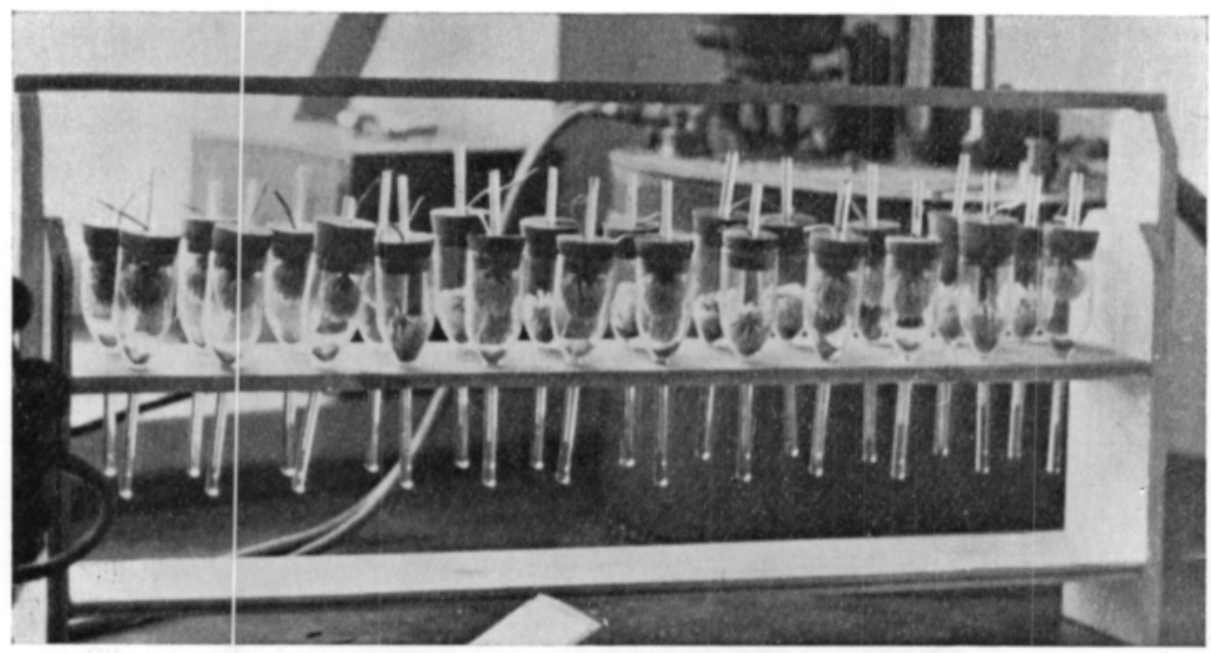

Figure 2: Glass tubes in the frame after centrifugation. The rotation speed of 3,500 r.p.m. has caused part of the stems to break. In the capillary tubes the nectar can be seen as a dark line, at the bottom of the broad upper part of the tube lies the metal gauze. 
Before this a small, concave, fine-meshed gauze (size of holes $0.7 \mathrm{~mm}$ ) is placed at the head of the capillary tube at the bottom of the broad part of the glass tube. This metal gauze prevents dirt which is loosened in centrifugation from being thrown into the capillary tube, which greatly facilitates the accurate measuring of the height of the nectar column. In experiments employing the above method of fastening it was proved that the head remained in position at a rotation speed of even 3,000 r.p.m., which corresponded to 1710 gms centrifugal force. At greater rotation speeds the stems began to break (Fig. 2).

Figures 1 and 2 also show the form of the glass tubes used: the total length is $16 \mathrm{cms}$, of which the broad upper part is $8 \mathrm{cms}$ and the capillary tube $8 \mathrm{cms}$. The diameter of the upper part is $3 \mathrm{cms}$ and the glass $2 \mathrm{mms}$ thick. About five cms from its mouth the tube begins to taper off towards the narrow capillary tube, which has a diameter of $1.5 \mathrm{mms}$. The inflorescences, even uncut, fit well into these glass tubes and the nectar is allowed to flow from them into the capillary tube, a process which is also aided by the gradual tapering off of the tube.

Swanson \& Shuel (13) in their experiments on nectar yield used $465 \mathrm{gms}$ centrifugal force and a centrifugation time of 6 minutes. An International Clinical centrifuge, in which there was room for four tubes, was employed. In the experiments carried out at the University Farm it was shown that the centrifugal force (corresponding to 1,500 r.p.m.) was insufficient for the extraction of the nectar, at least from uncut florets. An International size 2 Model V centrifuge was used in which 8 glass tubes fit simultaneously (Fig. 3). Several experiments were made to ascertain the necessary centrifugal force and centrifugation time for extracting the nectar. The nectar yields and sugar content of inflorescences of equal size

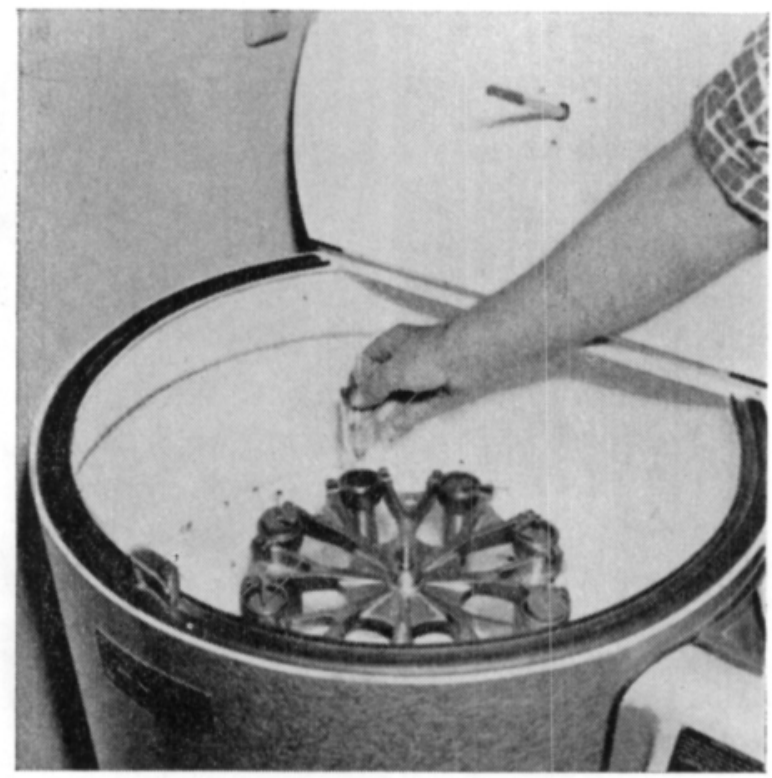

Figure 3. An International size 2 model V centrifuge used in the centrifuging of heads. 
and at the same blossom stage were measured $1 \frac{1}{2}, 3,6$, and 9 minutes after centrifugation. A speed of 2,000 r.p.m. corresponding to $760 \mathrm{gms}$ centrifugal force was already sufficieritly great to extract most of the nectar, but the centrifugation time showed no noteworthy significance with regard to the yield and quality of the nectar. Employing speeds of 2,500 and 3,000 r.p.m. corresponding to 1316 and 1710 gms centrifugal force, a slightly larger amount of nectar was obtained than at a speed of 2,000 r.p.m., but with an increase in the centrifugation time the sugar content decreased. The cause of this was believed to lie in the fact that other liquids, in addition to the nectar, had become mixed with it and were diluting it. Consequently, a speed of 2,500 r.p.m. was considered appropriate with a centrifugation time of 6 minutes of full speed.

\section{Measuring the nectar yield}

The nectar yield can be expressed per inflorescence in units of weight or volume, or correspondingly per 100 florets or grammes of inflorescence. At the University Farm it was decided to express the nectar yield in units of volume (microlitres) per 100 florets. If, in connection with the taking of a sample, it is possible to take approximately representative medium-sized inflorescences, it may be possible to express the nectar yield per medium-sized inflorescence without a great deal of inaccuracy. To ob:ain reliable results, however, the number of florets should be counted or at leas: the inflorescence should be weighed. The centrifuged nectar yield was obtained by measuring the height of the nectar column in the capillary tube with a millimetre scale (accuracy to $0.1 \mathrm{~mm}$.) and by multiplying the height with the coefficient indicating a volume of $1 \mathrm{~mm}$. This was ascertained by introducing $0.1 \mathrm{ml}$ of liquid into each tube with a pipette before use, and marking on the broad upper pert of the glass tube a number showing the length of the column of liquid, e.g. $5.4 \mathrm{cms}$ as in Fig 1 . In this tube a $1 \mathrm{~mm}$ column corresponds to 1.79 $\mu \mathrm{l}$ of nectar.

\section{Determination of the sugar content of the nectar}

When the nectar in the capillary tube had been measured, it was sucked into a fine pipette, from $\downarrow$ where it was transferred to a refractometre prism. A thermostat attached to the refractometre gave the nectar a temperature of $20^{\circ} \mathrm{C}$ at the moment of measuring ( $\mathrm{nI}$ ) 20). Having obtained the sucrose content in this way (5), the actual sugar content of the nectar is also quite accurately shown, because by far the greatest part of the nectar of red clover is sucrose (Park, 1932, ref. 1, p. 263). 
The paper gives an account of the method to measure the nectar yield of red clover heads. The method was developed at the University Farm at Viik in 1954, and based on two centrifugation methods employed earlier. The main attention was paid to the taking of the sample and its fast handling, because the heterogeneous nature of the material demands even in the case of one sample the examination of a considerably large number of heads.

The secretion of nectar and sugar was more abundant in the large heads than in the small-sized ones so that for the obtaining of realiable data with a moderate number of heads the sample should be composed of heads of as near the same size (medium size) as possible. The shortening of the corollas by cutting before centrifugation proved unnecessary at least where sufficiently large glass tubes were employed. By changing the method of fastening the inflorescences and the form of the glass tube, and by inserting a metal gauze at the bottom of the capillary tube the clean nectar was easily directed into the capillary tube (Figs. 1 and 2).

\section{REFERENCES}

(1) Boetius, J. 1948. Uber den Verlauf der Nektarabsonderung einiger Blütenpflanzen. Beihefte zur Schweizerischer Bienenztg. 17: 258-315.

(2) Braun, E., Mac Vikar, R. M., Gibson, D. R., Pankiw, P. \& Guppy, J. 1953. Studies in red clover seed production. Part II. Can J. of Agric. Sci 33: 437-447.

(3) Evert, R. 1939. Der Blutennektar. Leipziger Bienenztg. 54: 173-176.

(4) Gubin, A. F. 1936. Bestäubung und Erhöherung der Samenernte bei Rotklee Trifolium pratense L. mit Hilfe der Bienen. Arch für. Bienenkunde 17: 209-264.

(5) JАковS, M. 1938.' Chemical analysis of foods and food products. 537 p. New York.

(6) Johnsson, L. H. 1946. Nectar secretion in clover. Effect of soil and climate on honey production. New Zealand J. Agr. 73: 111-112.

(7) Pantela, J. \& Heinrichs, H. 1959. Puna-apilan kukkien mesipitoisuuden merkityksestä sen siementuotannossa. Summary: The effect of nectar content of red clover heads on the yield of seed. Maatal. ja koetoim. XIII: 167-178.

(8) Shuel, R. W. 1952. Some factors affecting nectar secretion in red clover. Pl. Physiol. 27: $95-110$.

(9) - - 1955 a. Nectar secretion in relation to nitrogen supply, nutritional status and growth of the plant. Can. J. of Agricult. Sci. 35: 124-138.

(10) - - 1955 b. Nectar secretion. American Bee Journal 95: 229-233.

(11) Shuel, R. W. \& Pedersen, M. W. 1952. The effect of environmental factors on nectar secretion as related to seed production. Proceedings of the sixth international grassland congress I: $867-870$.

(12) Stapel, Chr. \& Götzsche, O. 1941. Om Nektarsekretion og Kronrørslaengde mm. hos Rødkløveren under forskellige Gødningsforhold. Tidskr. for planteavl 46: 267-295.

(13) Swanson, C. A. \& Shuel, R. W. 1950. The centrifuge method for measuring nectar yield. Plant Physiol. 25: 513-524.

(14) Vanseli, G. H. 1943. Alfalfa nectar and the honey bee. Amer. Bee J. 83: 106-107. 
SELOST US :

\title{
PUNA-APILAN KUKINTOJEN MEDEN MÅ̊RITTÄMISEST Å
}

\author{
Juhani Paatela \& Hannes Heinrichs
}

\author{
Yliopiston kasvinviljelytieteen laitos, Helsinki
}

Tutkimuksessa on tehty selkoa Yliopiston opetus- ja koetilalla Viikissă v. 1954 kehitetystä medenmäärittämismenetelmästä, joka pohjautuu kahteen aikaisemmin käytettyyn sentrifugointimenetelmään $(3,4,12,13)$. Pääasiallinen huomio on kiinnitetty näytteen ottoon ja sen käsittelyyn päämääränä nopea mutta silti luotettava rutiinimenetelmä, koska erityisesti aineiston heterogeenisyys jo yhden näytteen osalta vaatii jopa $20-40$ kukinnon tutkimista.

Meden ja sokerin eritys oli suurissa kukinnoissa runsaampaa kuin pienikokoisissa, joten varmojen tulosten saavuttamiseł si pienillä kukintomäärillä näytteen tulee olla koostunut mahdollisimman samankokoisista (keskikokoi sista) kukinnoista. Teriöiden lyhentäminen leikkaamalla ennen sentrifugointia osoittautui tarpeettomaksi ainakin kyllin suuria lasiputkia käytettäessä. Myös kukinnon kiinnittämistapaa ja lasiputken muotoa muuttamalla sekä käyttämällä kapillaariputken suulla metallilankaverkkoa saatiin mesi helposti ja puhtaana valumaan kapillaariputkeen (kuvat 1-2). Käytettyä kiinnitystapaa kokeiltaessa tociettiin kukintojen pysyvän hyvin paikallaan vielă kierrosnopeuden ollessa 3000 kierr./min., mikä vastasi 1710 g:n keskipakoisvoimaa. Käytettävissä oli International-merkkinen (koko 2, malli V) sentrifuugi (kuva 3). Nopeus 1500 kierr./min. (vastaten 427 g:n keskipakoisvoimaa) ei vielä ollut riittävă meden irroittamiseksi ainakaan leikkaamattomista kukista. Kokeilujen tuloksena päädyttiin käyttämään nopeutta 2500 kierr./min. (= $1316 \mathrm{~g})$ sekä 6 minuutin sentrifugoimisaikaa, mikä laskettiin nopeuden saavuttamisesta lukien. Mesimääră ilmaistiin mikrolitroina $(\mu \mathrm{l})$ ja se saatiin helposti mitatuksi kun tunnettiin kapillaariputken läpimitta ja mesipatsaan korkeus. Siirtämällä hienopipetillä mettä lkapillaariputkesta Abben refraktometrin prismalle ja mittaamalla meden taitekerroin $\left(\mathrm{nD} 20^{\circ} \mathrm{C}\right)$ saitiin meden sukroosipitoisuus (5), joka lähimain ilmaisee myös meden todellisen sokeripitoisuuden, kotka valtaosa puna-apilan medestä on sukroosia. 